\title{
Sprawozdanie z realizacji projektu „Archiwa Rodzinne Niepodległej” w Archiwum Narodowym w Krakowie
}

W 2019 r. Archiwum Narodowe w Krakowie uczestniczyło wraz z innymi archiwami państwowymi w realizacji ogólnopolskiego projektu Naczelnej Dyrekcji Archiwów Państwowych pt. „Archiwa Rodzinne Niepodległej”. Jego celem było zwrócenie uwagi społeczeństwa na unikalną wartość rodzinnych pamiątek i aktywne zaangażowanie w dalsze świętowanie 100. rocznicy odzyskania przez Polskę niepodległości.

Projekt ten skierowany był głównie do osób posiadających w domowych zbiorach archiwalia, nieraz zapomniane i podniszczone. Miał zachęcić do otoczenia tych materiałów opieką i przywrócenia im dawnej świetności. Adresowany był również do tych wszystkich, którzy pamiętają i troszczą się o nie - a chcieliby to robić jeszcze lepiej.

W ramach inauguracji projektu „Archiwa Rodzinne Niepodległej” 30 września 2019 r. w siedzibie Archiwum Narodowego w Krakowie przy ul. Siennej 16 zorganizowano warsztaty „Zostań rodzinnym Archiwistą”. Wiedzę z zakresu prawidłowego porządkowania oraz właściwych zasad zabezpieczania i przechowywania dokumentów w domowych warunkach przekazali adeptom archiwistyki: Tomasz Wroński, pracownik Oddziału III - akt miasta Krakowa, samorządu terytorialnego, wyznaniowych, szkół i organizacji społecznych oraz Małgorzata Bochenek, kierownik Oddziału VIII - konserwacji i zabezpieczania zasobu archiwalnego.

Ponadto dr hab. Wojciech Krawczuk, dyrektor Archiwum Narodowego w Krakowie uhonorował darczyńców, dzięki którym wydano drukiem dzienniki i wspomnienia należące niegdyś do prywatnych kolekcji, a obecnie będące częścią zasobu krakowskiego Archiwum. Podczas warsztatów swoimi doświadczeniami na temat popularyzacji materiałów z rodzinnych archiwów i domowej edukacji historycznej podzielił się również Andrzej Madej.

Ogółem we wszystkich spotkaniach warsztatowych, połączonych częściowo z pokazami materiałów archiwalnych oraz z konsultacjami, uczestniczyło ponad 100 osób, w tym uczniowie szkoły podstawowej, genealodzy rodzinni, nauczyciele, bibliotekarze, muzealnicy i archiwiści.

Zgodnie z założeniami projektu „Archiwa Rodzinne Niepodległej” do zasobu Archiwum udało się także pozyskać ciekawe kolekcje z archiwów domowych.

Kolekcja rodziny Stach, przekazana w darze przez Marka Kołodzieja, zawiera materiały archiwalne z lat 1905-1972. Składają się na nie m.in. fotografie i portrety, dokumenty osobiste oraz akta dotyczące służby wojskowej i pracy zawodowej Jana Stacha, żołnierza Armii generała Hallera, następnie Wojska Polskiego, uczestnika wojny polsko-ukraińskiej i polsko-bolszewickiej, z zawodu szewca. W kolekcji tej wart wyróżnienia jest ciekawy wizualnie album z tablicami przedstawiającymi wzory obuwia zaprojektowane przez J. Stacha.

Druga z kolekcji ofiarowana została przez Krystynę Jelonek-Litewkę. Dotyczy Jana Steca, żołnierza Legionów Polskich i Wojska Polskiego, z zawodu zootechnika. Składa się 
z dokumentacji z lat 1912-1983 zawierającej informacje na temat jego służby wojskowej, w tym m.in. z notatek, fotografii, własnych życiorysów, dokumentów podróży, kart służbowych, zaświadczeń, książeczki poborowej, karty legitymacyjnej, wykazów żołnierzy 3. kompanii i kompanii technicznej 13. Pułku Piechoty Wojska Polskiego, programu kursu szturmowego, wykazu regulaminów i instrukcji dla oficerów rezerwy, instrukcji wewnętrznej dla kursów oficerów rezerwy, rozkazów, fragmentu dziennika personalnego, akt sądu honorowego, gazet i wycinków prasowych. Szczególnie cenne wydają się artykuły z prasy codziennej na temat odzyskania przez Polskę niepodległości i wyzwolenia Krakowa w 1918 r., z naniesionymi odręcznie przez J. Steca, świadka tamtych wydarzeń, uwagami. Znaczący jest też, powstały w 1919 r., noszący klauzulę „tajne”, Program ośmiotygodniowego kształcenia szturmowego, ułożony przez instruktorów szkoły szturmowej Dowództwa Okręgu Generalnego „Kraków”, w tym również przez ppor. J. Steca.

Wybrane akta z ww. kolekcji oraz z archiwów rodzinnych będących w posiadaniu: Marii Anny Król (kolekcja rodziny Pawlików), Jolanty Krupy (kolekcja rodziny Pisulów), K. Jelonek-Litewki (kolekcja rodziny Jelonków), Marii Masior (kolekcja rodziny Masiorów) zostały umieszczone na stronie internetowej projektu: https://archiwarodzinne.gov.pl/.

Tomasz Wroński

Archiwum Narodowe w Krakowie 